\title{
Branching onsets in Brazilian Portuguese
}

\author{
Thais Cristófaro-Silva \\ Universidade Federal de Minas Gerais \\ $\mathrm{KCL}$
}

\section{Resumo}

Este artigo discute o cancelamento de líquidas em encontros consonantais tautossilábicos no português brasileiro (PB). Esse fenômeno é denominado "redução de encontros consonantais tautossilábicos". Na primeira seção eu considero variações que ocorrem em onsets ramificados e procuro identificar motivações para a reducão de encontros consonantais tautossilábicos no PB. Nessa seção apresento ainda uma revisão da literatura sobre o tema e discuto a distribuição de encontros consonantais tautossilábicos em relação às vogais orais e nasais, ditongos e o acento tônico no PB. Na segunda seção são discutidas as conseqüências da redução de encontros consonantais tautossilábicos para a estrutura sonora do PB e eu procuro a maneira mais adequada para abordar o fenômeno em análise. Na terceira seção eu sugiro que a redução de encontros consonantais tautossilábicos não pode ser plenamente compreendida a não ser que a relação entre o léxico e o uso deste seja considerada. Meu objetivo é mostrar que a redução de encontros consonantais tautossilábicos pode ser mais bem analisada como um caso de difusão lexical. Eu sugiro que a separação de um item lexical em duas formas distintas - como conseqüência de lexicalização - é evidência para a difusão lexical. Outros casos de variação e mudança sonora no PB corroboram essa proposta. 
This paper addresses the loss of liquids in tautosyllabic consonantal clusters in Brazilian Portuguese (henceforth BP).

1 I refer to this phenomenon as branching onset reduction. In the first section, different types of variations concerning branching onsets will be considered and the potential motivation for branching onset reduction in $\mathrm{BP}$ will be investigated. Then, a review of previous work is presented and the distribution of branching onsets in relation to oral and nasal vowels/diphthongs and stress is discussed. I intend to look for structural conditioning factors which may favour branching onset reduction. In the second section, I will discuss some consequences of branching onset reduction for BP sound structure. I claim in the third section that branching onset reduction is not fully understood unless the relationship between the lexicon and its usage is addressed. The aim will be to show that branching onset reduction in $\mathrm{BP}$ is better understood as a case of lexical diffusion. I argue that the splitting of an item into different forms - through lexicalization - is evidence for lexical diffusion. Evidence from other cases of sound variation and change in $\mathrm{BP}$ is provided.

\section{ON BRANCHING ONSETS IN BP}

Brazilian Portuguese has tautosyllabic consonantal clusters. In such clusters the first consonant is an obstruent and the second one is a liquid. The obstruents $-\mathrm{p}, \mathrm{b}, \mathrm{t}, \mathrm{d}, \mathrm{k}, \mathrm{g}, \mathrm{f}, \mathrm{v}-$ combine with the liquids $-1, r-$ yielding to a cluster except for the following structural restrictions: $/ \mathrm{tl} /$ has a very restricted distribution and never occurs word-initially; /dl/ never occurs; /vr/ does not occur word-initially and /vl/ occurs in few loan words (CRISTÓFARO-SILVA, p. 1999b). 
All dialects of BP have tautosyllabic clusters. These clusters are subject to changes, which I list below. In some dialects all the (obstruent-lateral) clusters occur as (obstruent-vibrant) sequences. This occurs for example amongst speakers from around Itajubá (MG). Thus, words which in standard BP are pronounced as [bl]usa "blouse" or bicilkl]eta "bicycle" occur in these dialects as [brlusa and bici[kr]eta. This tends to be socially stigmatized and it may be optional for some speakers. There are also cases where the liquid in a branching onset in standard BP turns out to occupy a postvocalic position: "to look for" occurs as [pr]ocurar or [por]curar. This is also stigmatized and to my knowledge it does not seem to affect all words in any dialect. It is somehow related to rural dialects. Another type of variation involves cases where the liquid is displaced to an adjacent syllable: pedra $\rightarrow$ [prelda "stone". These cases were attested amongst speakers from shanty towns around Belo Horizonte (MG) so they tend to be associated with lower class dialects. The displacement of the liquid does not occur for every word (for a list of words where this was observed see (cf. FREITAS (2001)). However, for the word "rape" the displacement of the liquid to the preceding syllable may be observed amongst speakers of all social classes: estupro $\rightarrow$ es/tulpro or es[tru]po. In this latter case it appears that different speakers have either form lexicalized. I am not familiar with any detailed work that deals with any of the cases mentioned above. In fact they should be addressed in detail within a crossdialectal perspective. In this paper I will deal with another specific type of variation involving branching onsets which is related to the loss of the liquid: $l i[v r]_{0} \rightarrow$ li[v]o "book".

Let us first explore the motivation for branching onset reduction. Branching onsets represent a complex syllable structure. Thus, one may argue that the reduction to a single consonant - the obstruent - aims at providing a simpler typological syllable pattern: (CV). According to this view, li[vr]o "book" is realized as li[v]o in order to provide a simpler syllable pattern. This does not seem to be the case since branching onsets may be created from (CVCV) sequences. That 
is, a sequence of two (CV) syllables becomes a (CCV) one: xílkara] $\rightarrow$ xi[kra] "cup". In this last case the new syllable pattern, (CCV), is typologically marked and more complex than the former syllable sequence (CVCV). One could argue that antepenultimate stressed words are rare in Portuguese so that the change in xicara "cup" from xílkara] to xí[kra] aims at achieving the most common stress pattern in BP which is penultimate. Again this does not seem to be the case because penultimate stressed words such as "mouth ulcer" afta are typically pronounced with antepenultimate stress - affitta - since epenthesis takes place. In order to account for the change in stress - from penultimate [áfta] to antepenultiamte [áfita] - one could say that epenthesis occurs in order to avoid heterosyllabic clusters involving obstruents. This does not seem to hold either, since vowel deletion yields to consonant clusters where two obstruents occupy a postvocalic position: leques "hand fan" le[kis] $\rightarrow$ le[ks].

The arguments given above show that branching onset reduction does not take place in order to alter syllable structure or to simplify the stress system. I claim that the loss of the liquid reflects the fact that, like vowels, the liquids are rated high on the sonority scale and are thus subject to deletion. Thus, the motivation for branching onset reduction is the segmental structure of the liquid.

Let us then consider how branching onset reduction in BP has been approached in the literature. It has been observed that tautosyllabic consonantal clusters may be reduced to a single consonant (CRISTÓFARO-SILVA, 1992; LOPES \& SANTOS, 1995). When branching onset reduction occurs, the liquid is cancelled and the obstruent remains. This process is claimed to be optional. In (1) I present data from CRISTÓFARO-SILVA (1992).
(1)
a. exem[plo]
$\sim \operatorname{exem}[p o]$
b. ou[tro]
ou[to]
"example"
c. sem[pre]
$\sim \operatorname{sem}[p e]$
d. li[vro]
$\sim$ li[vo]
"other"
e. [bra]sileiro
$\sim$ [ba]sileiro
"always"
"book"
"Brazilian" 

f. [fla]mengo $\sim$ [fa]mengo
"Flamengo"
g. com/pri]mido $\sim$ com[pi]mido
"tablet"
h. com[pli]cado $\sim$ com[pi]cado
"complicated"

CRISTÓFARO-SILVA (1992) assumes that branching onset reduction is an optional process in which the cluster may be reduced only if the vowel that follows it is unstressed. Thus, in forms such as exem[plo] $\rightarrow$ exem[po] "example" and [bra]sileiro $\rightarrow$ [ba]sileiro "Brazilian", branching onset reduction is attested because the cluster is followed by an unstressed vowel. On the other hand, in a form such as [pra]to "plate", the branching onset cannot be reduced because it is followed by a stressed vowel: [pr]ato $\rightarrow$ *[pa]to "plate". However, further research has shown that branching onset reduction may also occur when the cluster is followed by a stressed vowel. Examples from CRISTÓFARO-SILVA (1999a; 2000a) are given below:
a. es/krelvo
es/kelvo
"I write"
b. [tri ]ta
[tĩ]ta
"thirty"
c. a[bra]ço
$a[b a] c o$
"hug"
d. com[prei]
com[pei]
"I bought"

The data presented so far show that the branching onset may be followed by an unstressed or stressed vowel (cf. $(1,2)$ ). Most examples that were given so far present oral vowels. In (3) I provide some data with branching onsets followed by oral diphthongs (3ab), nasal vowels (3c-d) and nasal diphthongs (3e-f).

$\begin{array}{llll}\text { (3) } & \text { [pra]ia } & \sim \text { [pa]ia } & \text { "beach" } \\ \text { b. enconltrei] } & \sim \text { encon[tei] } & \text { "I met" } \\ \text { c. [prĩ]cesa } & \sim \text { [pĩ]cesa } & \text { "princess" } \\ \text { d. en[trõ]camento } & \sim \text { en[tõ]camento "junction" } \\ \text { e. encon[trão] } & \sim \text { encon[tão] } & \text { "they meet" } \\ \text { f. pa[trão] } & \sim \text { pa[tão] } & \text { "boss" }\end{array}$

The context in which branching onset reduction applies seems to be when the cluster is followed by a vowel or a diphthong. Since all branching onsets in BP are followed by a vowel or diphthong, 
we conclude that any branching onset may potentially be reduced in BP. Let us now consider cases where more than one branching onset occurs. LOPES and SANTOS (1995) showed that words that contain two branching onsets are likely to have one of the clusters reduced to a single consonant. In (4) I illustrate cases which present a sequence of branching onsets.
a. problema
b. driblar
c. flagrante
d. deflagrado
e. retrógrada
f. programa
g. frustrado
h. próprio

In (4a-d) there is a sequence of branching onsets where the liquid is different for each member of a cluster in the sequence. In (4a-b) there is a sequence such as $(\mathrm{Cr})$ followed by $(\mathrm{Cl})$ and in $(4 \mathrm{c}-\mathrm{d})$ there is a sequence such as $(\mathrm{Cl})$ followed by $(\mathrm{Cr})$. In the examples in (4e-h) both onsets are $(\mathrm{Cr})$. Words where both onsets in the sequence are of the type $(\mathrm{Cl})$ were not found. For all words that have a sequence of branching onsets, the reduction to a single consonant is very common. Either branching onset may be reduced or both may be. Of course, both may be pronounced as well. That is, problema "problem" may occur as either of the forms: [problelma, Iprobelma, [poblelma, Ipobelma.

In this section we have seen that any branching onset may potentially be reduced in BP. The vowel that follows the branching onset may be oral, nasal or a diphthong and the syllable that contains the branching onset may be in a stressed or in an unstressed position. This means that we are facing an optional process. Optional processes usually involve variation of some type, which may be regulated by structural and non-structural factors. This will be addressed later. An important question arising from the facts discussed above is whether all words that present a branching onset 
have an alternative form where the branching onset is reduced. I will return to this question later. In the following section I discuss some consequences of our findings for the BP sound structure.

\section{CONSEQUENCES OF BRANCHING ONSET REDUCTION}

Before I specifically address whether or not any branching onset may be reduced in $\mathrm{BP}$, it is important to consider a process that involves the palatalization of alveolar stops when followed by a high vowel (which may be oral, nasal or non-syllabic). This process applies to most Southeastern dialects of BP, amongst others. In (5) "Dialect A" refers to dialects where palatalization occurs and "Dialect B" refers to dialects where palatalization does not happen.

\begin{tabular}{|c|c|c|c|}
\hline Example & Dialect A & Dialect B & Glossa \\
\hline a. tia & [t $5 i] a$ & [ti]a & "aunt" \\
\hline tinta & {$\left[t \int \tilde{i}\right] t a$} & {$[t \tilde{i}] t a$} & "paint" \\
\hline sorte & $\operatorname{sor}\left[t \int i\right]$ & sor $[t i]$ & "luck" \\
\hline pátio & pált $\left.\int y u\right]$ & pá[tyu] & "yard" \\
\hline dia & {$[d 3 i] a$} & {$[d i] a$} & "day" \\
\hline jardim & $\operatorname{jar}[d z i]$ & $\operatorname{jar}[d \tilde{\imath}]$ & "garden" \\
\hline g. tarde & $\operatorname{tar}[d 3 i]$ & $\operatorname{tar}[d i]$ & "late" \\
\hline ódio & $o ́[d 3 y u]$ & ó[dyu] & "hate" \\
\hline
\end{tabular}

Since the process illustrated above applies whenever an alveolar stop is followed by a high vowel, we do not expect to find any BP word that displays a sequence such as (alveolar stop+high vowel). This is because palatalization is expected in such sequences. Consider the examples in (6).
(6) a. [tĩ]ta
"thirty"
b. Itis/teza
"sadness"
c. ele[ti]cista
"electrician"
d. Aldilana
"Adriana"
e. po[di]
"rotten"
f. qualdillátero
"quadrilateral" 
An important point concerning the forms in (6) is that all of them have an alternative pronunciation where a liquid intervenes between the stop and the high vowel: [trĩ]ta; [tris]teza; ele[tri]cista; Aldri]ana; po[dri]; qualdri]latero. ${ }^{1}$ What is of interest here are forms such as [tĩ]ta "thirty" (cf. (6a)) and $\left[t \int i\right]$ ta "paint" (cf. (5b)) in dialects where palatalization applies. We have to explain why palatalization is not triggered in [tĩ ]ta "thirty" although an (alveolar stop+high vowel) occurs. This is because palatalization is triggered when an (alveolar stop+high vowel) sequence occurs: [t $\left.\int \tilde{i}\right] t a$ "paint".

Notice that speakers will be aware that a form like [tĩ ]ta "thirty" has an alternative pronunciation with a liquid intervening between the alveolar stop and the high vowel - [tri ]ta - and a form such as [t $\left.\int \tilde{i}\right] t a$ "paint" does not have an alternative pronunciation in dialects where palatalization applies.

These facts can easily be formalized within phonological frameworks. I will consider both a non-linear and an Optimality Theory analysis. CRISTÓFARO-SILVA (1999c) discusses palatalization of alveolar stops in $\mathrm{BP}$ within a non-linear perspective. According to this analysis, palatalization is triggered when a high front vowel is adjacent to the alveolar stop. ${ }^{2}$ Thus, in [t $\tilde{i} \tilde{i}$ ta "paint", palatalization takes place because the high front vowel is adjacent to the alveolar stop. Let us then consider examples such as "thirty" - which has alternative pronunciations: [tĩ] ta and [tri] Ita. In [trĩ] ta the liquid is syllabified and in [tĩ ]ta the liquid is not syllabified although it is present in the phonological representation. We should not expect palatalization to apply in [ti ] ta "thirty" because it is the adjacency between the high front vowel and the alveolar stop which triggers palatalization. This is because in [tĩ ]ta "thirty" the high vowel is not adjacent to the alveolar stop since the unsyllabified liquid intervenes between them. Within this perspective one has to assume that what motivates branching onset reduction is the search for a simpler syllable pattern where the liquid is not interpreted. In the first section we have seen that this is not the case. Within this view it is also not clear to address what regulates either optional form to occur. 
BARLOW and GIERUT (1999) analyse cluster reduction in language acquisition within the Optimality Theory (henceforth OT) framework. Concerning branching onset reduction, their analysis accounts for forms such as $/ \mathrm{blo} /$ and $/ \mathrm{bo} /$ "blow" in terms of constraint ranking: MAX: Segments in the input must correspond to segments in the output (No deletion); ONSET: A syllable must begin with a consonant and *COMPLEX: Avoid consonant clusters. The ranking is *COMPLEX $>>$ MAX $>>$ ONSET for $/ \mathrm{blo} / \rightarrow[\mathrm{bo}]$ and it is MAX $>>*$ COMPLEX $>>$ ONSET for $/ \mathrm{blo} / \rightarrow$ [blo] (BARLOW and GIERUT (1999, p.1493)). A similar analysis could be proposed for the facts discussed above which also involve branching onset reduction where the ranking of constraints would provide either output (with or without the branching onset). As in the non-linear analysis mentioned in the previous paragraph, branching onset reduction in OT is accounted for by taking into consideration specific aspects of segmental identity (MAX) and syllable structure (ONSET, *COMPLEX). As was pointed out in the first section, alteration in syllable structure is not the motivation for branching onset reduction. There is likewise little motivation to explain the choice for different ranking of constraints yielding to the potential outputs.

I have claimed in the first section that the loss of the liquid in branching onset reduction is due to its high sonority rather than to any aspect related to change in BP syllable structure or stress pattern. Thus, it seems to me that both theories mentioned above have little to say about the motivation for branching onset reduction since these proposals are mainly based on aspects related to syllable structure. However, it has been noticed that the motivation or actuation of a sound change is not necessarily related to the way the change is implemented (OLIVEIRA, 1991; PHILLIPS, 1998). I am interested in how branching onset reduction has been implemented in BP. Thus, from now on I will refrain from discussing the actuation of this change.

The phonological theories discussed above seem to have little to say about the choice for outputs (with or without a branching onset). In other words, the way branching onset reduction is 
implemented cannot be addressed. I argue that branching onset reduction does not reflect an optional process, nor is it a result of the ranking of different constraints. It is better understood as a case of sound change which has been implemented lexically. I will assume the lexical diffusion proposal to deal with how the change that involves branching onset reduction in BP has been implemented.

\section{SEARCH FOR AN EXPLANATION}

We have seen that no structural factor, such as the adjacent vowel or stress, conditions the alternation in branching onsets. ${ }^{3}$ It remains to be seen whether non-structural factors contribute or not to branching onset reduction. I selected as non-structural factors sex, age, education, geographic area, frequency of the item and style. Sex, age and education will be better addressed after the completion of the quantitative analysis. However, preliminary results show that these are not significant. LOPES and SANTOS (1995) observed branching onset reduction amongst speakers of five distinct regions in Brazil, which indicates that the phenomenon applies to various (if not all) geographic areas. Branching onset reduction may be widely observed in the media with speakers from different Brazilian states. Thus, it remains to address the role of the frequency of the item and style as non-structural factors, and this will be pursued in this section. The discussion of these two issues will support the diffusionist perspective I propose for branching onset reduction in BP.

In order to address the role of frequency and style, I believe it is important to address the main points raised by theories, which deal with sound variation and change. I would like here to recall the neogrammarian controversy. The neogrammarian position argues that sound changes are phonetically gradual and lexically abrupt. Within this view, a sound change is distinguished from borrowing and analogy. Contrary to the neogrammarian position we have the diffusionist perspective, which claims that a sound change is phonetically abrupt and lexically gradual. HARRIS (1989) and 
KIPARSKY $(1988,1995)$ use Lexical phonology to provide evidence for the neogrammarian position. LABOV $(1981,1994)$ attempts to conciliate both neogrammarian and diffusionist views. However, there has always been evidence that the role of the lexicon is fundamental in understanding sound changes and thus supporting the diffusionist perspective (CHEN, 1969; OLIVEIRA, 1991, 1995; PHILLIPS, 1998).

HINSKENS et al (1997) discuss a number of issues related to sound variation and change. Interestingly, they consider the neogrammarian controversy as still being a polemical issue, which deserves further consideration. This paper intends to contribute to this discussion. LABOV (1981) attempts to conciliate neogrammarian changes with lexical diffusion. This proposal was clearly refuted by OLIVEIRA (1991). After addressing various types of sound change he concludes that all sound changes are implemented by lexical diffusion. A similar conclusion was reached by OGURA (1995) (apud PHILLIPS, 1998).

HINSKENS et al (1997) explore KIPARSKY's (1995) proposal that a change that is lexically diffuse may be analysed as a case of analogy. The change will affect the lexicon item by item. According to Kiparsky, lexical diffusion happens to a rule that has become unproductive. He claims that lexical diffusion is a case of analogical change.

PHILLIPS (1998) addresses important issues raised in KIPARSKY (1995) providing very good arguments against the latter claim that lexical diffusion is identical to lexical analogy. She argues that lexical diffusion is a method of implementation, which applies to both phonetically gradient changes and phonetically abrupt changes. She also shows that it may affect the most frequent words first or the least frequent. KIPARSKY's (1995) proposal that lexical diffusion is a case of analogical change is not adequate.

Given the issues raised above, I would like to return to a question which I raised earlier: Can any form which presents a branching onset also present an alternative form where the branching onset sequence is reduced to the obstruent? I claim that the answer 
to this question is yes. However, whether or not alternative pronunciation is attested depends on the speaker's own lexicon and the use s/he makes of it. Following OLIVEIRA's (1995) proposal I intend to show that it is the use speakers make of a lexical item in a given context that actually regulates whether a form with or without a branching onset occurs. I will address this issue by considering the frequency of an item and style.

In considering frequency I would like to discuss some data gathered at the university. In this environment, words such as livro "book" or biblioteca "library" have a high frequency rate. Interestingly, branching onset reduction for the words li[vu] and bi[bi]oteca is also very high. This would support the assumption that the frequency of an item is important when addressing a change. However, if we take, for example, a word such as eletricista "electrician", which of course is not used as often as "book" and "library", we have surprising results. Even in elicitated data we have an extremely high rate of branching onset reduction amongst the same speakers, yielding ele[ti]cista. This latter case gives us evidence that high frequency of an item does not seem to be a relevant issue when discussing changes (cf. PHILLIPS, 1998). This is because items, which are very frequent or very occasional, display the change.

Still under the discussion of frequency and incorporating in it the issue of style, I would like to discuss data related to the word progresso "progress" in two specific situations. Progresso is the name of a neighbourhood in Belo Horizonte (Minas Gerais, Brazil). Thus, speakers who live in this area of town use the word very often. Interestingly, either [progre]sso, [pogre]sso, [proge]sso or [poge]sso are attested, with forms displaying branching onset reduction having a higher occurrence rate (cf. discussion under (4)). However, when talking to the same speakers about the Brazilian national flag - where the words Ordem e Progresso are written - it is observed that in this case the occurrence of [progre]sso - where both branching onsets occur - is much higher than in the case when progresso is the name of a neighbourhood. Of course, the Brazilian flag is associated with national 
issues which deserve respect and I believe that this may contribute to speakers' choice for the form /progre]sso (where both branching onsets usually remain) to be the most common pronunciation in this case.

OLIVEIRA (1995) proposes that the effect of frequency as well as style in sound changes should be derived from the context in which they occur. Features such as [ \pm frequent] or [ \pm formal] are attributed to lexical items in the contextual configurations in which they actually occur and not as a feature attributed to lexical items individually. Following LORD and ZUNG (1992), he assumes that the lexicon is viewed "as a plastic system which adapts to speakers' necessities" (OLIVEIRA, 1995, p. 87). The lexical model proposed by LORD and ZUNG (1992) aims at explaining "how speakers manage to acquire words, and put them into use (p. 349)". Consequently, we may understand why a lexical item, which has a high frequency rate, may or may not exhibit a change. We may also justify why the same lexical item displays a specific type of behaviour under certain contextual circumstances (as in progresso in the Brazilian flag) but an opposite type of behaviour under other circumstances (as in progresso being the name of a neighbourhood).

Finally, I would like to point out that in all cases regarding sound changes in BP, which supported a lexical diffusion perspective, we observe lexicalized forms for different speakers, or the same speaker makes use of two distinct lexicalized forms. OLIVEIRA (1991) discusses the raising of pretonic mid vowels indicating some lexicalized forms such as porção as [por]ção "portion" or [pur]ção "many"; folbinha as [fo]lhinha "little leaf" or [fu]lbinha "calendar". MADUREIRA (1997) deals with the vocalization of the lateral palatal within a diffusionist model, presenting lexicalized forms such as "old" velbo ve[yo], "hay" palba pa[ya], "to work" trabalbar traba[ya]r. CRISTÓFARO-SILVA (2000b) discusses the process of lateral vocalization in postvocalic position showing that forms such as melro "a type of bird" which occurs either as m[ewr]o or m[ewh]o are lexicalized differently for different speakers. I suggest that these cases give evidence that in a sound change there will be lexicalized forms 
either in competition or used interchangeably by the same speaker. Further evidence should follow from other languages.

Notice that I am not suggesting that lexicalized forms indicate that a sound change is underway. I would like to demonstrate this by considering cases in BP where a voiced bilabial stop replaces a voiced labiodental fricative. This happens usually amongst lower class speakers and in rural dialects in words such as vassoura "broom", varrer "to sweep" that occur systematically as [ba]ssoura, [ba]rrerfor the above mentioned speakers. As far as I am aware, this happens systematically only in these words. If we consider a word such as "whistle", it occurs for most speakers of all social classes either as asso[b]io or as asso[v]io. Considering the word "brave", this occurs as bralvol for most speakers but there has been the newly competing form bralbo/ which has a distinct meaning for some speakers (meaning "extremely brave"). Except for these cases that I have pointed out, a voiced labiodental fricative is not replaced by a voiced bilabial stop. That is, a word such as vaca "cow" is never pronounced as [ba]ka. In the case I have considered in this article, which involve branching onset reduction, it is possible to identify lexicalized forms such as: [d $\mathrm{i} \mathrm{ibr}] \mathrm{ar}$ "to dribble" (competing with [dribl]ar etc.), paldzi i nho "Godfather" (competing with paldrilnho) supporting the claim stated above.

\section{CONCLUSION}

In this paper I have discussed branching onset reduction in Brazilian Portuguese, and have shown that no structural factor conditions it. Amongst non-structural factors, I have addressed frequency and style. I have argued that branching onset reduction in BP reflects a case of lexical diffusion. Following LORD and ZUNG (1992) I suggest that the lexicon be interpreted as a plastic system which adapts to speakers' necessities. I have also claimed that sound changes always present lexicalized forms either in competition or used interchangeably by the same speaker. 


\section{NOTAS}

* I would like to thank the 30th Linguistic Symposium on Romance Languages participants for their questions and comments which contributed to the present format of this paper. I am very grateful to Marco Antônio de Oliveira for valuable discussions of issues dealt with in this paper. All errors are, of course, my own.

${ }^{1}$ Only [r] occurs in this case due to distributional restrictions indicated in the first section.

${ }^{2}$ This process applies through spreading from properties from the high vowel into the previous position. This analysis, interprets segmental content in terms of elements as proposed in Kaye, Lowenstamm and Vergnaud (1985).

${ }^{3}$ It is part of my research project to provide a comprehensive analysis of branching onset reduction in BP taking into consideration structural and non-structural factors in quantitative terms. However, since this is not yet completed I intend here to explore the qualitative data I have gathered and present results at the current research stage.

${ }^{4}$ In Portugal the situation is different and [v] may be replaced by [b] in extended environments.

\section{REFERENCES}

BARLOW, Jessica; GIERUT, Judith. Optimality Theory in Phonological Acquisition. Journal of Speech, Language and Hearing Research, v. 42, p. 1482-1498, 1999.

CHEN, M.; Wang, W.S-Y. Sound change: actuation and implementation. Language. 51, n. 2, p. 255-281, 1975.

CRISTÓFARO-SILVA, Thaïs. Nuclear Phenomena in Brazilian Portuguese. 1992. PhD, University of London.

. Difusão Lexical: Estudos de Casos do Português Brasileiro. Research project: Departamento de Lingüística da FALE-UFMG, 1999a.

. Fonética e Fonologia do Português-Roteiro de estudos e Guia de Exercícios.

São Paulo: Editora Contexto, 1999b.

. Palatalization in Brazilian Portuguese. ms. Submitted to appear in

S. Ploch \& G. Williams (ed). SOAS. London, 1999c. 
CRISTÓFARO-SILVA, Thaïs. Sobre a quebra de encontros consonantais no português brasileiro. Estudos Lingüísticos XXIX, Unesp, SP, v. 29, p.522-526, 2000 a.

Lateral Vocalization in Brazilian Portuguese. ms. Belo Horizonte, 2000b.

FONTES-MARTINS, Raquel. O cancelamento das líquidas e intervocálicas no português contemporâneo de Belo Horizonte. 2001. Dissertation (MA) - UFMG.

FREITAS, Edir. Estrutura silábica CCV e aprendizagem da escrita. 2001. Dissertation (MA) - UFMG.

HARRIS, John. Towards a lexical analysis of sound change in progress. Journal of Linguistics, n. 25, p. 35-56, 1989.

HINSKENS, F. von Hout; WETZELS, Leo. Um balanço de dados e teoria no estudo da variação e da mudança fonológica. In: Letras de Hoje, v. 35, n. 1.7-46, 1997. (Translated from: Variation, change and phonological theory. John Benjamins, 1997).

KAYE, Jonathan, Jean Lowenstamm and Jean-Roger Vergnaud. The Internal Structure of Phonological Elements: A theory of charm and government. Phonology Yearbook 2. p. 305-328, 1985.

KIPARSKY, Paul. Phonological Change. Linguistics: The Cambridge Survey. V. I. Ed. by F. Newmeyer. p. 363-415. Cambridge University Press, 1988.

. The phonological basis of sound change. The handbook of phonological theory. GOLDSMITH, J. A. (Ed.). Oxford: Blackwell, 1995.

LABOV, William. Resolving the neogrammarian controversy. Language 57 (2). p. 267-308, 1981.

1994

Principles of Linguistic Change. Vol. I. Internal factors. Oxford: Blackwell,

LESLAU, Wolf. Frequency as determinant of linguistic change in the Ethiopian languages. Word. 25, p. 180-189, 1969.

LORD, Robert and Chang Tsong Zung. How does the lexicon work? Word. V. 43, n. 3, p 349-373, 1992.

LOPES, Mário Alexandre; SANTOS, Monica. Encontros consonantais tautossilábicos no português brasileiro. Paper presented at Semana do NAPq na FALE-UFMG, 1995.

MADUREIRA, Evelyne. Difusão lexical e variação fonológica: o fator semântico. Revista de Estudos da Linguagem, Ano 6, n. 5, 1997. 
OLIVEIRA, Marco Antônio. Variável lingüística: conceituação, problemas de descrição gramatical e implicações para a construção de uma teoria gramatical. DELTA, São Paulo, v. 3, n. 1, p. 19-34, 1987.

The neogrammarian controversy revisited. International Journal of the Sociology of Language, v. 89, p. 93-105, 1991.

O léxico como controlador de mudanças sonoras. Revista de Estudos da Linguagem, Ano 4, n. 3, p. 75-92, 1995.

PHILLIPS, Betty. Word frequency and the actuation of sound change. Language 60, p. 320-342, 1984.

$\overline{1998 .}$

. Lexical diffusion is not lexical analogy. Word, v. 49, n. 3, p. 369-381,

PRINCE, Alan; SMOLENSKY, Paul. Optimality Theory: Constraint Interaction in Generative Grammar. Ms. Rutgers University, NJ. and University of Colorado at Boulder, 1993.

WANG, W. S-Y. Competing changes as a cause of residues. Language 45, n. 1. p. 9-25, 1969. 